\title{
WOOD PLANING PROPERTIES OF AUSTRALIAN PLANTATION-GROWN Eucalypts
}

\author{
${\text { Benoit Belleville }{ }^{I, ↔}, \text { Philip Ashley }}^{I}$, Barbara Ozarska ${ }^{I}$
}

\begin{abstract}
Planing properties of seven Australian plantation-grown eucalypts were evaluated to provide recommendations on how these species should be machined and considered for the manufacture of high quality furniture and furnishings. The surface quality produced for each species was evaluated using eight planing conditions. All species performed well producing equivalent or better results than mature traditional furniture species, and could be used for high value furniture manufacturing. Tungsten carbide cutters produced better results than high-speed steel for most eucalypts and the grinding of a small chip-breaker usually produced improving results as the size of the chip-breaker was reduced. Grain orientation did not affect the planed surfaces for some species but planing with the grain usually produced better surface. Recovery and presence of torn grain could not be related to the wood density.
\end{abstract}

Keywords: Eucalyptus, machining, planning, plantation, surface quality, surface roughness.

\section{INTRODUCTION}

The decline in Australia's native forest log harvests is closely linked with increases in log harvests from plantation estate and decreased availability of tropical rainforest timber species suitable for furniture and other appearance product (Ozarska 1997). Australian plantations produced more than $75 \%$ of the 20,2 million cubic metres of logs harvested in 2011 even if accounting for less than $2 \%$ of the country's 125 million hectares of forest area (ABARES 2013). Established mainly for the production of timber and wood-based products, it consists of similar areas of softwood species and hardwood species. Hardwood plantation area around the country has increased by more than $31 \%$ over the past ten years (Gavran and Parsons 2011). Eucalypt plantation forestry has developed rapidly in recent years and is now dominated by commercial species like southern blue gum (Eucalyptus globulus; $55,1 \%$ by area) and shining gum (Eucalyptus nitens 24,2\%) (Gavran 2012). Blackbutt (Eucalyptus pilularis) and flooded gum (Eucalyptus grandis) together comprise 2,7\% where spotted gum (Corymbia maculata) comprises 2,2\%. A further 5,6\% includes eucalypts like mountain ash (Eucalyptus regnans) and Sydney blue gum (Eucalyptus saligna). The hardwood plantation production in Australia could increase to more than 14 million cubic metres per year by 2030 (ABARES 2013) and eucalypt plantation forestry could eventually fully replace supplies from native forests (Nolan et al. 2005). Extensive research has been conducted so far on growing eucalypts in plantations and primary processing (VicForests 2010). However, secondary processing of Australian plantation hardwoods for high value wood products has received little attention.

The machinability of a species is of particular importance in order to assess the facility in processing raw material into products with good quality surfaces (Kopač and Šali 2003). Wood species vary greatly in their behaviour under cutting tools (Malkoçoğlu and Özdemir 2006, Porankiewicz and Goli

\footnotetext{
${ }^{1}$ The University of Melbourne, Faculty of Science, School of Ecosystem and Forest Sciences, Richmond, Victoria, Australia "Corresponding author: benoit.belleville@unimelb.edu.au Received: 26.08.2015 Accepted: 23.03.2016
} 
2014). It has been demonstrated that the properties of wood produced from intensively managed trees associated with short-rotation harvest are different from wood produced in natural stands (Bendtsen 1978). Thus, characterising the facility with which plantation-grown eucalypts can be machined into products where favourable machining properties are critical to good finish is essential. The project was designed to evaluate the potential of young eucalypts growing under short rotation planting conditions, as a resource for the manufacture of high quality furniture and furnishings. Planing operation was assessed to provide recommendations on how these species should be machined and which should be considered.

\section{MATERIAL AND METHODS}

Seven species were selected from a variety of locations in the south east of Australia, and ranged from 15 to 40 years in age (Table 1). 60 years of age Victorian ash (Eucalyptus regnans/delegatensis) was included as a comparison. The timber was selected from the butt log of the tree, and was cut from the heartwood at a location midway between the bark and pith. All of the timber was backsawn (Figure 1). Specimens were $35 \mathrm{~mm}$ thick, $40 \mathrm{~mm}$ wide, and $2 \mathrm{~m}$ long with moisture content (MC) of $10 \%$ prior to planing.

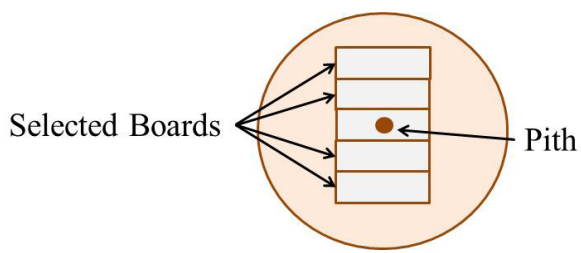

Figure 1. Sawing method used for timber preparation.

Table 1. Species included in the planing evaluation.

\begin{tabular}{|c|c|c|c|c|}
\hline Species & Origin & Age & Air dry density at $12 \% \mathrm{MC}\left(\mathrm{kg} / \mathrm{m}^{3}\right)$ & Mature wood ${ }^{\mathrm{b}}\left(\mathrm{kg} / \mathrm{m}^{3}\right)$ \\
\hline $\begin{array}{c}\text { Eucalyptus grandis } \\
\text { (flooded gum or rose gum) }\end{array}$ & $\begin{array}{l}\text { Macksville } \\
\text { Shepparton }\end{array}$ & $\begin{array}{l}28 \\
22\end{array}$ & $\begin{array}{c}691 \\
(11,6)^{\mathrm{a}} \\
721 \\
(15,4)\end{array}$ & 804 \\
\hline $\begin{array}{l}\text { Eucalyptus saligna } \\
\text { (Sydney blue gum) }\end{array}$ & $\begin{array}{l}\text { Shepparton } \\
\text { Mildura }\end{array}$ & $\begin{array}{l}25 \\
18\end{array}$ & $\begin{array}{c}779 \\
(10,4) \\
774 \\
(12,4)\end{array}$ & 806 \\
\hline $\begin{array}{l}\text { Corymbia maculata } \\
\text { (spotted gum) }\end{array}$ & $\begin{array}{l}\text { Lake Hume } \\
\text { Shepparton } \\
\text { Mildura }\end{array}$ & $\begin{array}{l}40 \\
25 \\
18\end{array}$ & $\begin{array}{c}871 \\
(5,5) \\
888 \\
(3,4) \\
798 \\
(6,8) \\
\end{array}$ & 969 \\
\hline $\begin{array}{c}\text { Eucalyptus camaldulensis } \\
\text { (river red gum) }\end{array}$ & Mildura & 17 & $\begin{array}{c}696 \\
(13,6)\end{array}$ & 854 \\
\hline $\begin{array}{l}\text { Eucalyptus sideroxylon } \\
\text { (red ironbark) }\end{array}$ & Lake Hume & 40 & $\begin{array}{c}925 \\
(6,8)\end{array}$ & 1,060 \\
\hline $\begin{array}{l}\text { Eucalyptus cladocalyx } \\
\text { (sugar gum) }\end{array}$ & Lake Hume & 40 & $\begin{array}{l}1,032 \\
(4,4)\end{array}$ & 1,035 \\
\hline $\begin{array}{l}\text { Eucalyptus globulus } \\
\text { (southern blue gum) }\end{array}$ & $\begin{array}{c}\text { Oxley } \\
\text { Alexandria }\end{array}$ & 16 & $\begin{array}{c}728 \\
(10,5) \\
703 \\
(6,1) \\
\end{array}$ & 843 \\
\hline
\end{tabular}

${ }^{a}$ Coefficient of variation or Ratio of the standard deviation to the mean (\%).

${ }^{\mathrm{b}}$ Air dry density of mature wood at $12 \%$ MC according to Kingston and Risdon (1961). 
The surface quality produced for each species was evaluated using eight planing conditions (Table 2) on a Weinig Hydromat 23 moulder (Oberkochen, Germany). The surface finish achieved was evaluated using two cutter materials, high-speed steel (HSS) and tungsten carbide (HW). Using HW cutters, the effect of three different chip-breaker settings $(2,1$, and $0,5 \mathrm{~mm})$, a cutter block using a shear angle and three different cutting angles $\left(30,25\right.$, and $\left.20^{\circ}\right)$ were evaluated (Figure 2). A $2 \mathrm{~mm}$ cut was removed for each condition. The feed speed for all conditions was $10 \mathrm{~m} \mathrm{~min}^{-1}$ to give a cutter pitch of $1,67 \mathrm{~mm}$ and cutter-head speed was $6000 \mathrm{rpm}$. Samples were fed through in order alternating through the species. Half of each group of timber was machined with the grain and the other half against the grain for each planing conditions. One thousand linear metres of the hardwood species were planed using every condition. In total, approximately seven thousand linear metres of timber was planed.

Table 2. Planing conditions.

\begin{tabular}{|l|c|c|c|c|c|c|c|c|}
\hline \multicolumn{2}{|c|}{$\begin{array}{c}\text { Cutter } \\
\text { Material }\end{array}$} & $\begin{array}{c}\text { Cutting } \\
\text { Angle }\end{array}$ & $\begin{array}{c}\text { Shear } \\
\text { Angle }\end{array}$ & $\begin{array}{c}\text { Chip } \\
\text { breaker } \\
(\mathrm{mm})\end{array}$ & $\begin{array}{c}\text { Tool } \\
\text { Diameter } \\
\text { \& cutter } \\
\text { extension } \\
(\mathrm{mm})\end{array}$ & $\begin{array}{c}\text { Grinding } \\
\text { Angle }\end{array}$ & $\begin{array}{c}\text { Clearance } \\
\text { Angle }\end{array}$ & $\begin{array}{c}\text { No of } \\
\text { Cutters }\end{array}$ \\
\hline 1 & HSS & $25^{\circ}$ & $0^{\circ}$ & 2 & 125 & $55^{\circ}$ & $15^{\circ}$ & 4 \\
2 & HW & $25^{\circ}$ & $0^{\circ}$ & 2 & 125 & $55^{\circ}$ & $15^{\circ}$ & 4 \\
3 & HW & $25^{\circ}$ & $0^{\circ}$ & 1 & 125 & $55^{\circ}$ & $15^{\circ}$ & 4 \\
5 & HW & $25^{\circ}$ & $0^{\circ}$ & 0,5 & $125 / 1$ & $55^{\circ}$ & $15^{\circ}$ & 4 \\
6 & HW & $25^{\circ}$ & $5^{\circ}$ & 1 & 125 & $55^{\circ}$ & $15^{\circ}$ & 2 \\
7 & HSS & $30^{\circ}$ & $0^{\circ}$ & 6 & $161 / 20$ & $34^{\circ}$ & $20^{\circ}$ & 2 \\
8 & HSS & $25^{\circ}$ & $0^{\circ}$ & 8 & $161 / 20$ & $40^{\circ}$ & $20^{\circ}$ & 2 \\
\hline
\end{tabular}

HSS: high-speed steel; HW: tungsten carbide
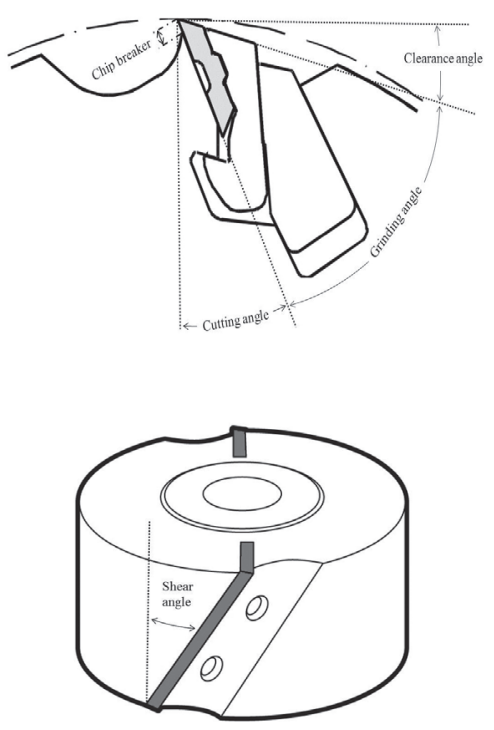

Figure 2. Cutter head and cutter knife geometry (adapted from Leitz 1997). 
The grading system used was developed by CSIRO/Holmesglen Institute which was based on the worst affected area of the machined surface (Waugh and Rozsa 1991). Two people using sight and touch method graded the planed surface. The defects checked for were torn grain (torn and chipped grain are referred to as torn grain), raised grain and chip marks. A score was assigned to the worst defect of each type: 5) Unacceptable with defect a lot beyond repair; 4) Unacceptable with defect just beyond repair; 3) Acceptable with heavy sanding but undesirable; 2) Acceptable with moderate sanding but undesirable; 1) Acceptable with light sanding; 0) No defect present. Then, the scores allocated were encompassed into the overall score: 1) No defects and good surface sheen (i.e. very light sanding required); 2) No defects but slight surface sheen, or good surface sheen but slightly rough (i.e. very light sanding required); 3) No defects but no surface sheen (i.e. light sanding required); 4) Defects of grade 1 only (i.e. light sanding required); 5) Defects of grade 1 and 2 (i.e. moderate sanding required); 6) Defects of grades 1, 2 and occasionally 3 (i.e. heavy sanding required); 7) Several defects of grade 3 (i.e. heavy sanding required and only suitable for unseen surfaces); 8) One defect of grade 4 or 5 (i.e. sanding uneconomical); 9) Several defects of grade 4 or 5 (i.e. extreme sanding required); 10) Numerous defects of grade 4 and 5 (i.e. considered beyond sanding). If no defects were present then the sample would score between one and three. A sample graded one to four would be considered acceptable in furniture manufacture. The percentage of pieces scoring one to four would determine the percentage recovery for that species.

\section{RESULTS AND DISCUSSION}

\section{Effect of cutter material on planing quality}

A higher percentage of defect free pieces (i.e. scoring 1-3) was achieved using HW cutters (planing condition 2) instead of HSS cutters (planing condition 1) with Eucalyptus saligna (+11\%), Eucalyptus grandis $(+11 \%)$ and Eucalyptus sideroxylon $(+7 \%)$ (Table 3$)$. Both cutters materials returned a $75 \%$ of defect free pieces with Eucalyptus camaldulensis. The HSS cutters produced a higher return of defect free pieces over the run of one thousand linear metres than HW cutters for Eucalyptus cladocalyx $(+15 \%)$ and Eucalyptus globulus $(+11 \%)$. However, this would probably be reversed if planing larger quantities of timber. According to the manufacturer, HSS cutters continue to wear while HW cutters will settle down after $1000 \mathrm{~m}$. Similar trend, although to a lesser extent, was observed with Corymbia maculata $(+5 \%)$ and Eucalyptus regnans/delegatensis $(+4 \%)$.

Table 3. Percentage of defect free pieces and pieces considered acceptable for furniture for each planing condition.

\begin{tabular}{|c|c|c|c|c|c|c|c|c|c|c|c|c|c|c|c|c|}
\hline \multirow[t]{2}{*}{ Planing condition } & \multicolumn{2}{|c|}{1} & \multicolumn{2}{|c|}{2} & \multicolumn{2}{|c|}{3} & \multicolumn{2}{|c|}{4} & \multicolumn{2}{|c|}{5} & \multicolumn{2}{|c|}{6} & \multicolumn{2}{|c|}{7} & \multicolumn{2}{|c|}{8} \\
\hline & 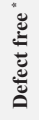 & 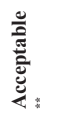 & 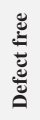 & 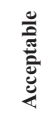 & 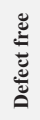 & 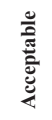 & 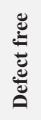 & 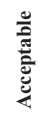 & 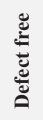 & 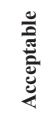 & 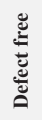 & 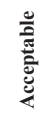 & 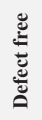 & 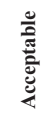 & 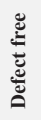 & 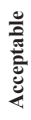 \\
\hline Eucalyptus regnans & 45 & 97 & 41 & 92 & 59 & 93 & 68 & 100 & 44 & 100 & 41 & 91 & 51 & 86 & 40 & 87 \\
\hline Eucalyptus globulus & 75 & 100 & 64 & 100 & 75 & 100 & 71 & 100 & 64 & 96 & 0 & 86 & 0 & 100 & 0 & 86 \\
\hline Eucalyptus saligna & 26 & 87 & 37 & 92 & 30 & 96 & 0 & 100 & 22 & 100 & 0 & 100 & 0 & 100 & 0 & 66 \\
\hline Eucalyptus grandis & 28 & 79 & 39 & 97 & 39 & 84 & 0 & 100 & 26 & 94 & 0 & 33 & 0 & 100 & 0 & 0 \\
\hline Corymbia maculata & 32 & 78 & 27 & 84 & 27 & 81 & 46 & 100 & 22 & 86 & 33 & 93 & 33 & 93 & 46 & 86 \\
\hline $\begin{array}{l}\text { Eucalyptus } \\
\text { camaldulensis }\end{array}$ & 75 & 100 & 75 & 100 & 37 & 100 & 25 & 100 & 25 & 87 & 25 & 75 & 25 & 100 & 25 & 50 \\
\hline $\begin{array}{l}\text { Eucalyptus } \\
\text { sideroxylon }\end{array}$ & 57 & 100 & 64 & 100 & 78 & 100 & 71 & 100 & 57 & 100 & 7 & 86 & 7 & 93 & 7 & 86 \\
\hline $\begin{array}{l}\text { Eucalyptus } \\
\text { cladocalyx }\end{array}$ & 53 & 100 & 38 & 92 & 50 & 100 & 57 & 100 & 57 & 93 & 14 & 71 & 36 & 100 & 21 & 71 \\
\hline
\end{tabular}

Eucalyptus camaldulensis, Eucalyptus sideroxylon and Eucalyptus globulus all offered a 100\% recovery (i.e. pieces acceptable for furniture manufacture scoring 1-4) using either of the cutters 
materials. The HW cutters produced significantly better recovery for Eucalyptus grandis compared to the HSS cutters $(+18 \%)$. Overall, the HW cutters produced better results than the HSS for most plantation eucalypts with the exception of Eucalyptus cladocalyx. Eucalyptus regnans recovery was also slightly higher using the HSS cutters.

\section{Effect of chip-breaker settings on planing quality}

The grinding of a small chip-breaker into the planer knives usually improved results as the size of the chip-breaker was reduced from 2 to $0,5 \mathrm{~mm}$ (planing conditions 2-4). A $100 \%$ of acceptable pieces were produced using the HW cutters with the $0,5 \mathrm{~mm}$ chip-breaker (planing condition 4 ) for all studied species. Reducing the size of the chip-breaker helped increase the number of defect free pieces for most species except Eucalyptus camaldulensis. The grinding of a $0,5 \mathrm{~mm}$ chip-breaker into the planer knives for Eucalyptus grandis and Eucalyptus saligna resulted in no defect free pieces.

\section{Effect of shear cutter on planing quality}

The use of a shear angle cutter (planing condition 5) achieved some improvements on the percentage of pieces considered acceptable when compared with planing condition 2 (i.e. HW cutters with a $2 \mathrm{~mm}$ chip-breaker) for Eucalyptus saligna, Eucalyptus cladocalyx, and Eucalyptus regnans. The shear cutter generally produced a larger percentage of pieces with defects. Based on obtained results, the use of a shear angle cutter would not be recommended as it gave only marginal improvements for the range of plantation eucalypts tested. Still, those results were good considering that the shear cutter used two knives and could be better if a cutter block with four knives had been available.

\section{Effect of cutting angle on planing quality}

The cutting angle on the range of tools used in the tests was between $20^{\circ}$ and $30^{\circ}$ (planing conditions 6-8). The surfaces produced generally worsened or remained the same as a result of reducing the cutting angle. Based on the percentage of pieces considered acceptable for furniture the optimum cutting angle was usually $25^{\circ}$ or $30^{\circ}$ for planing most of the species.

Since improvements gained by reducing the cutting angle might be at the expense of increasing the power consumption, reducing the cutter life and sometimes increasing the cutting noise, the highest cutting angle achieving one hundred percent of pieces acceptable for furniture is probably the optimum for that species. However, if the amount of sanding required is minimised this will in turn reduce labour costs, reduce costs on purchasing abrasives and reduce power costs for the sander. The cutting angle for planing cutter-heads currently used in the Australian furnishing industry is approximately $27^{\circ}$.

\section{Effect of planing with or against the grain on quality}

The grain orientation did not affect the planed surfaces for Eucalyptus globulus, Eucalyptus grandis, Eucalyptus camaldulensis, or Eucalyptus sideroxylon (Table 4). This observation is in accordance with de Moura Palermo et al. (2014) who found that surface roughness of Eucalyptus grandis after planing was not affected by feed direction. A higher percentage of pieces acceptable for furniture manufacture or fit for purpose (i.e. scoring 1-4) were produced when the timber was planed against the grain for Eucalyptus cladocalyx and Eucalyptus saligna. Planing with the grain produced better quality surfaces for Corymbia maculata. There was some minor difference in the quality of the surfaces produced when the wood was planed with or against the grain within a species from different origins. 
Table 4. Impact of planing with or against the grain on the percentage of pieces considered acceptable for furniture pieces and exhibiting torn grain or raised grain.

\begin{tabular}{|c|c|c|c|c|c|c|c|}
\hline & & \multicolumn{3}{|c|}{ With the grain } & \multicolumn{3}{|c|}{ Against the grain } \\
\hline Species & Origin & Acceptable & Torn grain & $\begin{array}{c}\text { Raised } \\
\text { grain }\end{array}$ & Acceptable & $\begin{array}{l}\text { Torn } \\
\text { grain }\end{array}$ & $\begin{array}{c}\text { Raised } \\
\text { grain }\end{array}$ \\
\hline \multirow{2}{*}{$\begin{array}{l}\text { Eucalyptus } \\
\text { grandis }\end{array}$} & Macksville & $100 \%$ & $50 \%$ & $0 \%$ & $100 \%$ & $37 \%$ & $0 \%$ \\
\hline & Shepparton & $100 \%$ & $100 \%$ & $0 \%$ & $100 \%$ & $100 \%$ & $0 \%$ \\
\hline \multirow{2}{*}{$\begin{array}{l}\text { Eucalyptus } \\
\text { saligna }\end{array}$} & Shepparton & $75 \%$ & $75 \%$ & $0 \%$ & $100 \%$ & $50 \%$ & $0 \%$ \\
\hline & Mildura & $88 \%$ & $66 \%$ & $11 \%$ & $100 \%$ & $57 \%$ & $0 \%$ \\
\hline \multirow{3}{*}{$\begin{array}{l}\text { Corymbia } \\
\text { maculata }\end{array}$} & Lake Hume & $100 \%$ & $50 \%$ & $0 \%$ & $85 \%$ & $85 \%$ & $0 \%$ \\
\hline & Shepparton & $100 \%$ & $50 \%$ & $0 \%$ & $100 \%$ & $50 \%$ & $0 \%$ \\
\hline & Mildura & $71 \%$ & $85 \%$ & $0 \%$ & $62 \%$ & $87 \%$ & $0 \%$ \\
\hline $\begin{array}{l}\text { Eucalyptus } \\
\text { camaldulensis }\end{array}$ & Mildura & $100 \%$ & $50 \%$ & $0 \%$ & $100 \%$ & $100 \%$ & $25 \%$ \\
\hline $\begin{array}{l}\text { Eucalyptus } \\
\text { sideroxylon }\end{array}$ & Lake Hume & $100 \%$ & $37 \%$ & $0 \%$ & $100 \%$ & $33 \%$ & $0 \%$ \\
\hline $\begin{array}{l}\text { Eucalyptus } \\
\text { cladocalyx }\end{array}$ & Lake Hume & $89 \%$ & $66 \%$ & $0 \%$ & $100 \%$ & $50 \%$ & $0 \%$ \\
\hline \multirow{2}{*}{$\begin{array}{l}\text { Eucalyptus } \\
\text { globulus }\end{array}$} & Oxley & $100 \%$ & $75 \%$ & $0 \%$ & $100 \%$ & $100 \%$ & $0 \%$ \\
\hline & Alexandria & $100 \%$ & $0 \%$ & $0 \%$ & $100 \%$ & $14 \%$ & $0 \%$ \\
\hline $\begin{array}{l}\text { Eucalyptus } \\
\text { regnans }\end{array}$ & $\begin{array}{c}\text { Central } \\
\text { Highlands }\end{array}$ & $100 \%$ & $29 \%$ & $0 \%$ & $100 \%$ & $40 \%$ & $0 \%$ \\
\hline
\end{tabular}

Pieces acceptable for furniture manufacture or fit for purpose (i.e. scoring 1-4). Backsawn (plainsawn) timber planed using the HW cutters with a $2 \mathrm{~mm}$ chip-breaker (planing condition 2).

\section{Planing quality comparison between species}

The results for each of the species after being planed using the HW cutters with the $2 \mathrm{~mm}$ chipbreaker (planing condition 2) was chosen for the comparison between species since it represents a commonly used planing set-up and it is similar to the conditions recommended in ASTM D-1666. Sharpness of HW cutters would also be more consistent than that for HSS cutters over the duration of a planing trial. The aim of this comparison was to give an indication of the facility each species can be machined. Eucalyptus regnans has been plotted alongside the young, plantation-grown eucalypts as a comparison.

The recovery of defect free pieces for all studied eucalypts could not be directly related to the wood air dry density $(A D D)$ (Figure 3). This observation is in accordance with Thoma et al. (2015) who studied the surface roughness of five different species after planing. However, the recovery for species such as Eucalyptus grandis and Eucalyptus globulus decreased drastically between locations as $A D D$ increased. An opposite trend was observed for Corymbia maculata where recovery increased from $13 \%$ to $50 \%$ as $A D D$ increased from 798 to $888 \mathrm{~kg} / \mathrm{m}^{3}$. Both locations for Eucalyptus saligna delivered a recovery of $37 \%$ defect free pieces. However, $A D D$ for the two sites were similar (i.e. 774 and $\left.779 \mathrm{~kg} / \mathrm{m}^{3}\right)$. 
Overall, the species performing the lowest results were Corymbia maculata, Eucalyptus saligna, Eucalyptus grandis and Eucalyptus cladocalyx. Interestingly, these species were out performed by Eucalyptus camaldulensis and Eucalyptus sideroxylon, two species figuring on either end of the ADD spectrum with $696 \mathrm{~kg} / \mathrm{m}^{3}$ and $925 \mathrm{~kg} / \mathrm{m}^{3}$, respectively. Most species produced equivalent or better results than Eucalyptus regnans (41\%) with the exception of Corymbia maculata. Eucalyptus globulus, Eucalyptus camaldulensis and Eucalyptus sideroxylon all produced $100 \%$ of timber acceptable for furniture manufacturing. Based on this result, all of the species would be able to be planed well enough to be used for high value wood furniture.

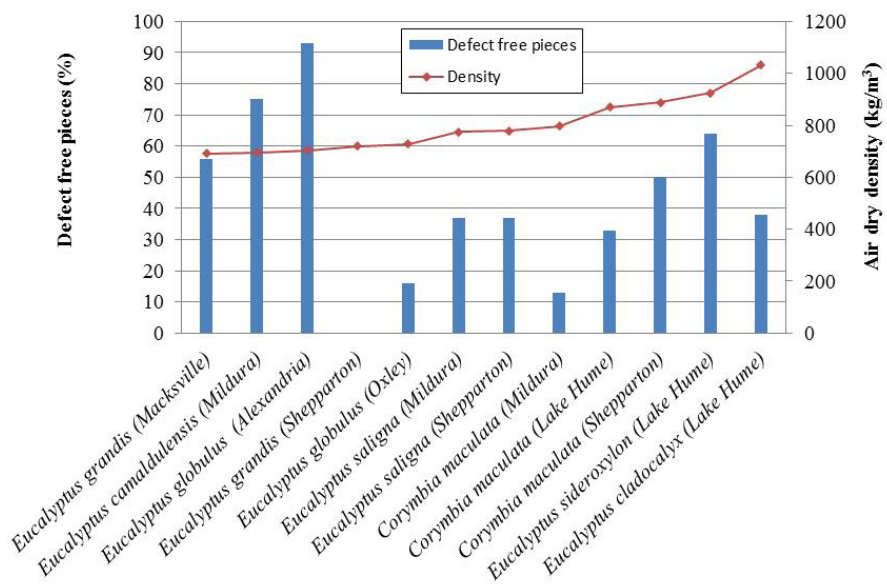

Figure 3. Air dry density and recovery of defect free pieces per species after being planed using the HW cutters with the $2 \mathrm{~mm}$ chip-breaker (planing condition 2).

Eucalyptus globulus provided $64 \%$ of defect free pieces and the maximum return of pieces acceptable for furniture. It also produced the smallest amount of torn grain, here $32 \%$ (Table 5, planing condition 2). Eucalyptus sideroxylon produced similar results with $64 \%$ of defect free pieces and $36 \%$ of pieces exhibiting torn grain. Both species produced less torn grain than Eucalyptus regnans $(51 \%)$ where the other species produced slightly more (61-76\%). Corymbia maculata produced the most torn grain $(76 \%)$, and this defect contributed solely to the $16 \%$ reject rate, as this species showed no raised grain. The presence of torn grain was not linked to the density of the species. Eucalyptus camaldulensis also exhibited a large percentage of torn grain (75\%), although not deep enough to affect the reject rate. Only three plantation species exhibited raised grain when planed under planing condition 2 . Eucalyptus camaldulensis exhibited $12 \%$ of raised grain compared to the other species, although not serious enough to affect the reject rate. Raised grain is more likely to occur with lower density species such as Eucalyptus camaldulensis as demonstrated by Davis (1962). 
Table 5. Percentage of pieces exhibiting torn or and raised grain after each planing condition.

\begin{tabular}{|c|c|c|c|c|c|c|c|c|c|c|c|c|c|c|c|c|}
\hline \multirow{2}{*}{$\begin{array}{l}\text { Planing } \\
\text { condition }\end{array}$} & \multicolumn{2}{|c|}{1} & \multicolumn{2}{|c|}{2} & \multicolumn{2}{|c|}{3} & \multicolumn{2}{|c|}{4} & \multicolumn{2}{|c|}{5} & \multicolumn{2}{|c|}{6} & \multicolumn{2}{|c|}{7} & \multicolumn{2}{|c|}{8} \\
\hline & อ & 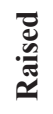 & हี & 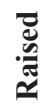 & อี & 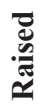 & อี & 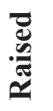 & อี & 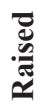 & 苞 & 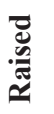 & है & 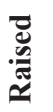 & อี & 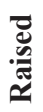 \\
\hline $\begin{array}{l}\text { Eucalyptus } \\
\text { regnans }\end{array}$ & 27 & 41 & 51 & 4 & 41 & 0 & 24 & 10 & 49 & 6 & 47 & 16 & 50 & 4 & 50 & 11 \\
\hline $\begin{array}{l}\text { Eucalyptus } \\
\text { globulus }\end{array}$ & 11 & 18 & 32 & 4 & 21 & 3 & 28 & 16 & 32 & 4 & 86 & 16 & 86 & 43 & 100 & 0 \\
\hline $\begin{array}{l}\text { Eucalyptus } \\
\text { saligna }\end{array}$ & 57 & 26 & 62 & 4 & 65 & 4 & 66 & 33 & 78 & 0 & 100 & 66 & 100 & 33 & 100 & 33 \\
\hline $\begin{array}{l}\text { Eucalyptus } \\
\text { grandis }\end{array}$ & 55 & 31 & 61 & 0 & 61 & 3 & 100 & 66 & 71 & 10 & 100 & 0 & 100 & 0 & 100 & 0 \\
\hline $\begin{array}{l}\text { Corymbia } \\
\text { maculata }\end{array}$ & 62 & 27 & 76 & 0 & 73 & 5 & 53 & 0 & 80 & 0 & 66 & 6 & 66 & 0 & 53 & 0 \\
\hline $\begin{array}{l}\text { Eucalyptus } \\
\text { camaldulensis }\end{array}$ & 75 & 25 & 75 & 12 & 62 & 0 & 75 & 0 & 87 & 0 & 75 & 0 & 50 & 25 & 75 & 0 \\
\hline $\begin{array}{l}\text { Eucalyptus } \\
\text { sideroxylon }\end{array}$ & 50 & 7 & 36 & 0 & 21 & 0 & 28 & 0 & 43 & 0 & 93 & 0 & 93 & 0 & 93 & 7 \\
\hline $\begin{array}{l}\text { Eucalyptus } \\
\text { cladocalyx }\end{array}$ & 26 & 20 & 61 & 0 & 50 & 0 & 36 & 0 & 43 & 0 & 86 & 0 & 64 & 0 & 78 & 0 \\
\hline
\end{tabular}

\section{CONCLUSIONS}

This project provides the necessary technical information on machining of a number of potential hardwood species which have met tree growth and primary processing requirements regarding their potential for high quality furniture and furnishing products. The data obtained within this study will allow optimising the machining process of plantation-grown wood in Australia and increase value from the current plantation resource.

All species performed well producing equivalent or better results than mature traditional furniture species, and could be used for high value furniture manufacturing. Tungsten carbide cutters produced better results than high-speed steel for most eucalypts and the grinding of a small chip-breaker usually produced improving results as the size of the chip-breaker was reduced. Grain orientation did not affect the planed surfaces for some species but planing with the grain usually produced better surface. Recovery and presence of torn grain could not be related to the wood density. 


\section{REFERENCES}

ABARES. 2013. Australia's State of the Forests Report 2013. Australian Bureau of Agriculture and Resource Economics and Sciences. Canberra, Australia. 464 p.

ASTM. 2011. D 1666-87. Standard test methods for conducting machining tests of wood and wood-based materials. American Society for Testing and Materials, Philadelphia, PA.

Bendtsen, B.A. 1978. Properties of wood from improved and intensively managed trees. Forest Prod J 28(10):61-72.

Davis, E.M. 1962. Machining and related characteristics of United States hardwoods. USDA Tech. Bull. 1267. For. Prod. Lab., Madison, Wis.

de Moura Palermo, G.P.; de Figueiredo Latorraca, J.V. ; de Moura, L.F. ; Nolasco, A.M. ; de Carvalho, A.M. ; Garcia, R.A. 2014. Surface roughness of heated Eucalyptus grandis wood. Maderas-Cienc Tecnol 16(1):3-12.

Gavran, M. 2012. Australian Plantation Statistics 2012 Update. ABARES technical report. Australian Bureau of Agricultural and Resource Economics and Sciences.

Gavran, M.; Parsons, M. 2011. Australian Plantation Statistics 2011, Australian Bureau of Agricultural and Resource Economics and Sciences.

Kingston, R.S.T.; Risdon, C.J.E. 1961. Shrinkage and Density of Australian and Other SouthWest. Pacific Woods. CSIRO Division of Forest Products. Tech. Paper No. 13.

Kopač, J.; Šali, S. 2003. Wood: an important material in manufacturing technology. J Mater Process Technol 133:134-142.

Leitz. 1997. Leitz Lexicon - A comprehensive tool selection catalogue. Gebr. Leitz GmbH \& co., Oberkochen, Germany.

Malkoçoğlu, A.; Özdemir, T. 2006. The machining properties of some hardwoods and softwoods naturally grown in Eastern Black Sea Region of Turkey. J Mater Process Technol 173:315-320.

Nolan, G.; Greaves, B.; Washusen, R.; Parsons, M.; Jennings, S. 2005. Eucalypt plantations for solid wood products in Australia - A Review. Forest and Wood Products Research and Development Corporation. $138 \mathrm{p}$.

Ozarska, B. 1997. Introduction to Australian research on utilising native hardwoods for high value-added wood products. WIN-Woodworking international, 1/97 pp. 52-53.

Porankiewicz, B.; Goli, G. 2014. Cutting forces by oak and douglas fir machining. MaderasCienc Tecnol 16(2):199-216.

Thoma, H.; Peri, L; Lato, E. 2015. Evaluation of wood surface roughness depending on species characteristics. Maderas-Cienc Tecnol 17(2):285-292.

VicForests. 2010. Plantations - complementing Victoria's native forest timber. VicForests, Melbourne, Australia. 2 p. 
Waugh, G.; Rozsa, A.N. 1991. Grade descriptions. CSIRO Forestry and Forest Products \& Holmesglen Institute, Internal Report. 